\title{
Exploring the personality of sportswear brands
}

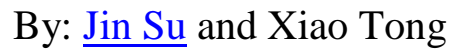

Tong, X., \& Su, J. (2014). Exploring the personality of sportswear brands. Sport, Business and Management: An International Journal, 4(2), 178-192.

Made available courtesy of Emerald: http://dx.doi.org/10.1108/SBM-08-2012-0032

****) Emerald. Reprinted with permission. No further reproduction is authorized without written permission from Emerald. This version of the document is not the version of record. Figures and/or pictures may be missing from this format of the document. ***

\begin{abstract}
:
Purpose - The purpose of this paper is to identify the personalities that are associated with sportswear brands and tests the applicability of Aaker's brand personality framework in the context of sportswear brands.
\end{abstract}

Design/methodology/approach - This study employed Aaker's brand personality framework to empirically investigate the personality of sportswear brands based on data collected from 420 college students.

Findings - Results revealed that consumers perceive seven distinct personality dimensions and 53 personality traits in sportswear brands: Competence, Attractiveness, Sincerity, Innovation, Activity, Excitement, and Ruggedness.

Originality/value - This research developed a valid and reliable scale that measures personality for sportswear products and confirms that consumers do associate particular brand personality dimensions with sportswear brands. The findings would help managers in the sportswear market better understand the image of their brand in the minds of consumers and better distinguish their brand from competing brands.

Keywords: Brand personality | Brand personality dimensions | Sportswear

\section{Article:}

\section{Introduction}

In contemporary consumer societies, people purchase products not only for what the products can do (i.e. their physical attributes and functional benefits) but also for what they symbolize, and the symbolic qualities of products are often the primary reasons for a consumer's purchase (Maehle et al., 2011). This symbolic meaning that brands acquire is often called brand personality, which Aaker (1997) defines as "the set of human characteristics associated with a brand" by (p. 347). Previous studies (Sung and Tinkham, 2005; Sung and Kim, 2010) indicate that a brand's personality can be formed from both product-related factors and factors not related 
to the product (e.g. the consumer's past experience, user imagery, symbols, marketing communication, word of mouth, CEO image, celebrity endorsers). The notion of brand personality appears to have been a highly recognized topic for marketing scholars and practitioners in recent years. Drawing upon the pioneering work of Aaker (1997), consumer and brand researchers have given a considerable amount of attention to the construct of brand personality; business marketers have also been fascinated by the conceptual and practical implications of brand personality and its potential in branding strategies and marketing practices (Arora and Stoner, 2009).

Although many studies have been conducted on brand personality, and existing brand personality dimensions and scales are well-established, most research is mainly based on a set of brands across product categories (Aaker, 1997; Aaker et al., 2001). Previous studies have suggested that personality perceptions may vary by product category and that specific brand personality dimensions are associated with particular product categories (Cui et al., 2008; Arora and Stoner, 2009; Kaplan et al., 2010). The sportswear industry represents a large and growing market worldwide, and sportswear brands are dedicated to getting customers' attention and building brand loyalty through creating a strong brand image (Tong and Hawley, 2009). Considering that few studies have been done to specifically identify the personalities of sportswear brands, this research takes a customer perspective to examine the personalities that are specifically associated with sportswear brands and tests the applicability of Aaker's brand personality framework in the context of sportswear brands. More specifically, it aims to answer two research questions: first, do sportswear brands possess a personality, as posited by Aaker (1997), and if so, what are the underlying dimensions of the personality of sportswear brands? Second, although it appears that the brand personality framework of Aaker (1997) has proven to be widely applicable, little is known about its applicability in the sportswear brands context. Hence, this study also aims to test that.

\section{Review of the literature}

\section{Perspectives on brand personality}

The notion that inanimate objects such as brands can become associated with human characteristics has been given a considerable amount of attention in marketing and consumer research (Sung and Kim, 2010). Brands reflect the complete experience that customers have with products. The concept of personality is usually attributable to humans; however, this notion can also be used to define the characteristics of a non-human being. Previous studies asserted that consumers find it natural to build relationships with brands (Fournier, 1998) and to imbue them with different personality characteristics, such as "active" or "confident"; thus the symbolic and emotional use of brands is possible (Aaker, 1997; Plummer, 2000). The concept of brand personality offered in the literature recognizes the use of human descriptors to portray brands (Plummer, 2000; Freling and Forbes, 2005; Geuens et al., 2009; Maehle et al., 2011). More formally, the most widely cited definition of brand personality is the following: "the set of human characteristics associated with a brand" (Aaker, 1997, p. 347). Hence, brand personality outlines who a brand is as a "personage" and/or "character." 
Anthropomorphic theory offers an explanation for why people tend to grant human qualities to brands (Aggarwal and McGill, 2007; Maehle et al., 2011). Anthropomorphizing non-human objects, and a brand in particular, is a natural tendency, because people try to explain objects in terms of their own experiences and conceptions (Aggarwal and McGill, 2007).

Anthropomorphizing makes non-human products seem more humanlike and more familiar; thus, consumers gain comfort and reassurance when interacting with products they have anthropomorphized. By ascribing human characteristics to products, consumers decrease their uncertainty in a complex, ambiguous purchasing, and consumption environment. The theory of the "extended self” developed by Belk (1988) also helps explain why brands are provided with personality. Belk (1988) maintains that "possessions are a major contributor to and reflection of our identities" (p. 139). Brand personality enables consumers to identify themselves with a brand and to express their own personality through the brand, as individuals tend to consider possessions to be part of their "self" (Belk, 1988; Azoulay and Kapferer, 2003). Sirgy's (1982) self-congruity theory also provides conceptual linkages relevant to brand personality. The selfcongruity theory holds that consumers compare their self-concept with the image that a brand projects and, in turn, prefer brands that are consistent with their self-concept. Studies have found support for the notion that consumers choose products and services that they feel possess personalities that are similar to (congruent with) their own (Sirgy, 1982; Phau and Lau, 2001; Escalas and Bettman, 2005; Arora and Stoner, 2009).

Marketers and brand managers view brand personality as an efficient way to distinguish a brand from its competitors, thereby enhancing the effectiveness of marketing communications efforts (Arora and Stoner, 2009; Sung, 2011). Furthermore, since the dimension of brand personality appears to be less imitable than other product attributes, it may yield a more sustainable competitive advantage (Ang and Lim, 2006). In the increasingly competitive and complex business environment, consumers often have difficulty in distinguishing brands based on physical attributes and functionality; therefore, brand personality offers an effective way to achieve product differentiation. Brand personality influences consumers' perceptual processing of product information and may create a basis for differentiation (Freling and Forbes, 2005), which impacts what customers think and feel about brands and further impacts what customers do. Thus, brand personality is a central driving force of a consumer's positive attitude toward and preference for a brand (Biel, 1993). From a consumer's point of view, brand personality provides self-expressive or symbolic benefits (Aaker, 1999; Sung and Kim, 2010). Brands can add meaning to a consumer's life through their status as a partner in a relationship (Fournier, 1998; Caprara et al., 2001; Sung and Tinkham, 2005), which further helps create and build meaningful consumer-brand relationships. Consumers purchase and use brands to meet their needs; to create, reinforce, and communicate their personalities; and to form their self-brand connections, which facilitate the expression of actual or ideal dimensions of the self (Belk, 1988; Escalas and Bettman, 2005; Sung and Tinkham, 2005; Sung and Kim, 2010; Sung, 2011).

\section{Brand personality measurement and its dimensions}

A profusion of research on brand personality has been particularly noticeable since the pioneering work of Aaker (1997), who carried out widely applicable, widely cited, and arguably the most influential research on the brand personality scale (Cui et al., 2008; Kaplan et al., 2010). Aaker (1997) attempted to adapt the "Big Five" model to brands. Big Five is a human 
psychology model that classifies and organizes the determinants of human personality into five dimensions: extraversion, agreeableness, conscientiousness, emotional stability (or neuroticism), and openness. Although there is a debate about the relative roles of situation and personality in behavior, the Big Five model is now widely accepted as a valid description of human personality traits (Avis, 2012).

Aaker's (1997) research was aimed at assessing and describing the aggregate structure of brand personality across brands and product categories (Sung and Tinkham, 2005; Cui et al., 2008). Aaker (1997) conducted extensive research by carefully selecting 37 brands from various product categories and adopting a lexical approach similar to the Big Five model. From the original set of 114 traits, Aaker (1997) developed a 42-item measurement scale called the brand personality scale and identified five distinct personality dimensions that are associated with brands, which she labeled as Excitement, Sincerity, Competence, Sophistication, and Ruggedness:

- $\quad$ sincerity is typified by traits such as wholesome, down-to earth, and honest;

- excitement is typified by traits such as daring, spirited, and imaginative;

- competence is typified by traits such as reliable, intelligent, and successful;

- $\quad$ sophistication is typified by traits such as glamorous, upper-class, and charming; and

- ruggedness is typified by traits such as outdoorsy, masculine, and tough.

Aaker found that the framework of these five brand personality dimensions, as represented by the 42-item scale, is reliable, valid, and generalizable, and appears to best explain the way American consumers perceive brands across symbolic and utilitarian product and service categories. However, Aaker's brand personality concept definition and scale have been criticized in regards to the exclusion of negative factors (Bosnjak et al., 2007; Avis, 2012), concerns about cultural specificity (Bosnjak et al., 2007; Milas and Mlačić, 2007; Geuens et al., 2009), the inclusion of items that are not proper personality traits (Azoulay and Kapferer, 2003; Bosnjak et al., 2007; Geuens et al., 2009; Avis, 2012).

Other researchers have also sought to develop factor models of brand personality. For example, Bosnjak et al. (2007) identified and operationalized indigenous German brand personality attributions. They also developed a 20-item instrument proposed for the parsimonious measurement of brand personality attributions in the German cultural domain. In their study, they proposed a four-factor structure, including drive (exciting, adventurous, boring); conscientiousness (competent, orderly, reliable); emotion (loving, cordial, sentimental); and superficiality (selfish, arrogant, hypocritical). Geuens et al. (2009) developed a measure for brand personality which consists of 12 items and five factors (activity, responsibility, aggressiveness, simplicity, and emotionality), and their scale shows an affinity with the Big Five human personality dimensions. Previous studies also indicated that several brand personality dimensions have similar meanings in different cultures, while other dimensions are culturespecific (Aaker et al., 2001; Sung and Tinkham, 2005; Bosnjak et al., 2007).

All of the analyses by Aaker (1997) involving the brand personality framework were aggregated across a wide variety of product categories (Austin et al., 2003). Similarly, most of her later studies (Aaker et al., 2001; Sung and Tinkham, 2005; Bosnjak et al., 2007; Milas and Mlačić, 
2007; Geuens et al., 2009) measure brand personality on an aggregate level across multiple brands of different product categories. However, studies have suggested that personality perceptions may vary by product category and different settings, and that specific brand personality dimensions are associated with particular product categories (Arora and Stoner, 2009). Moreover, prior research applied the Aaker's (1997) framework in specific sectors and offered unique variations of personality dimensions that were drawn from a particular market context. For example, Ekinci and Hosany (2006) argued that Aaker (1997) brand personality scale can be extended to gauge personality traits that tourists ascribe to destinations, and their study results indicate that personality of a tourist destination can be described in three dimensions: Sincerity, Excitement, and Conviviality. Later, a study by Kaplan et al. (2010) identified two new dimensions - namely malignancy and conservatism - as unique dimensions of brand personality for cities. The results of a study by Kim et al. (2010) studied dimensions of news media brand personality and found five brand personality dimensions that can be applicable to that field: trustworthiness, dynamism, sincerity, sophistication, and toughness. In addition, by extending Aaker's (1997) work, Chen and Rodgers (2006) developed an instrument to measure web site personality and Venable et al. (2005) investigated brand personality in nonprofit organizations. Therefore, there is a need to define brand personality measurement scales adapted to a particular product category and sector.

\section{Personality of sportswear brands}

According to a definition supplied by the Sporting Goods Manufacturers Association, sportswear is "a product purchased with the intent that it will be used in active sport" (Newbery, 2009). The sportswear industry is expected to exceed $\$ 163$ billion by 2016 (just-style.com, 2009), spurred by a trend toward healthier, more active lifestyles and demand from specific demographics such as teenagers, baby boomers, and women consumers. Product innovation continues to be key in the sports clothing industry, with companies employing product design and technological innovation to keep up with changing trends in fitness. Increasing emphasis on versatility, performance, convenience, comfort, and also fashionable style is creating a strong demand for sportswear, which offers both functional performance and style appeal. Sports lovers wear stylish sportswear in order to look smart and fashionable when they do exercise (Lau et al., 2006). Thus, there is a growing trend of major sports apparel companies partnering with famous designers to introduce innovative and stylish sports apparel (Lau et al., 2006).

The global sportswear market is highly competitive and is one of the most heavily branded segments in the global apparel market (Tong and Hawley, 2009). It is dominated by a few major international players, such as Nike, Adidas, and Reebok. According to just-style.com (2009), brands have about 75 percent of the sportswear market worldwide, and the top two players alone, Adidas and Nike, are believed to control 40 percent of the world market. Therefore, branding remains the industry's largest source of competitive advantage, and sportswear brands are dedicated to using a distinct and memorable brand identity to get customers' attention and build brand loyalty (Tong and Hawley, 2009).

Similar to the situation with other consumer goods and brands, perceptions of the personality traits of sportswear brands can be formed and influenced by the direct and/or indirect contact that the consumer may have had with sportswear brands (Plummer, 1985). Personality traits can be 
associated with sportswear brands in a direct way, through corporate reputation, product quality, shopping, and usage experience (Aaker, 1997). In an indirect manner, personality traits can be attributed to sportswear brands through marketing programs such as advertising, sports and event sponsorships, athlete-celebrities, and the media construction of sports (Ekinci and Hosany, 2006). Although there have been sparse empirical investigations at the group level, the validity of the personality of sportswear brands has been embraced by a few studies at the individual brand level (Ambroise et al., 2005; Arora and Stoner, 2009; Brakus et al., 2009). For example, through an analysis of measuring brand personality using French consumers, Ambroise et al. (2005) revealed that Nike and Adidas were represented with personality attributes such as "charming," "reliable," and "creative." Brakus et al. (2009) posited that consumers' experience with Nike was portrayed as being "powerful," "inspired," and "feel like an athlete." Furthermore, Arora and Stoner (2009) found that Nike was perceived by American consumers as "authority" and "innovative," while Adidas was perceived as more "friendly" and "practical." Accordingly, the aim of this current study is to identify brand personality dimensions within the sportswear category (not at the individual brand level) by using the brand personality framework developed by Aaker (1997).

\section{Research design and methodology}

\section{Selection of brand personality attributes}

Guided by the brand personality study by Aaker (1997), the selection of sportswear brand personality attributes followed a three-step process. In the first step, we conducted a freeassociation task to ensure familiarity and relevance of the attributes. In total, 80 undergraduates at a large southeastern university (60 percent female, average age $=22$ ) were asked to write down the personality attributes that first came to mind when thinking about well-known sportswear brands. Based on a research report on sportswear brands from Commerzbank (2008), the top ten sportswear brands by market share were chosen as the product stimuli in this study: namely Nike, Adidas, Reebok, Puma, New Balance, Converse, K-Swiss, Sketchers, Under Armour, and ASICS. A total of 210 unique traits were generated in this process. Second, in order to maximize the content representation of personality attributes, we incorporated the 42 original personality traits proposed by Aaker (1997) into our inventory, because those attributes were compiled and developed from diverse sources such as the Big Five personality factors and other refined scales used by academics and practitioners (Sung and Tinkham, 2005). We identified 32 additional attributes from the study of personality characteristics of athletic brands by Arora and Stoner (2009) and the Brakus et al.'s (2009) study of brand experience of athletic brands yielding a total of 284 attributes. Guided by the Aaker et al. (2001) brand personality study, the third stage looked to reduce the 284 attributes to a more manageable number by eliminating "redundant" ( $n=75$; e.g. cool arose from the free-association task as well as from Aaker 1997); "ambiguous" ( $n=62$; e.g. normal, colorful, nice); and "irrelevant to the construct" ( $n=84$; e.g. giving, profitable, football). This resulted in a final set of 63 traits being used to examine the sportswear brands' personality.

\section{Sample and procedure}


This study is exploratory research which investigates personality characteristics associated with sportswear brands. Therefore, a generalizable sample is not required (Yin, 1989). A convenience sample was selected also due to cost and time advantages (Kumar, 1999). We used a sample of college students in this study, because young people, including college students, constitute the largest and most important target market for sportswear, as their physically active lifestyle creates a strong demand for sportswear products (Deng, 2009). A total of 460 copies of the questionnaire were hand-delivered to students enrolled at two large universities in USA (one from the north, one from the south), and 420 responses were found usable. The participants ranged in age from 18 to $30(\mathrm{M}=21)$. In total, 70 percent of the sample were female. The most prevalent ethnic group was Caucasian (77.4 percent), followed by African-American (10.3 percent), Asian (8.4 percent), and Hispanic or Latino (1.1 percent).

Although listing a large number of brands increases the generalizability and validity of the scale, an excessively lengthy questionnaire may create a negative effect on participants, which could result in a response bias (Aaker, 1997). To overcome this bias, each participant was given the questionnaire for only one brand in this study. Respondents were first asked to pick one sportswear brand from the list of top ten sportswear brands (Nike, Adidas, Reebok, Puma, New Balance, Converse, K-Swiss, Sketchers, Under Armour, and ASICS) they were most familiar with; then the participants received a modified version of the Aaker (1997, p. 350) instructions (see below); and finally they were asked to rate the extent to which the 63 personality traits described their most familiar sportswear brand along a scale that ranged from 1 (not at all descriptive) to 5 (extremely descriptive). To control for order effects, the personality attributes in the questionnaire were presented in random order:

If I asked you to give me your impression of a particular person, you might answer with a set of personality attributes. Now, let's think about brands in the same way. In this study, we are interested in finding out your perception of human personalities associated to your most familiar sportswear brand. While evaluating the subsequent set of attributes, please ask yourself, "If this sportswear brand was a person, how would you describe him/her?".

\section{Data analysis and results}

\section{Exploratory factor analysis (EFA)}

In order to ensure the validity of the study, we followed the Aaker (1997) method (Kim et al., 2010), randomly splitting the data set into two equal samples: an estimation sample and a validation sample. Based on the random half of the data set $(n=210,420 / 2)$, we first examined personality dimensions of sportswear brands through EFA using principal component analysis with varimax rotation.

During the EFA, seven items loaded on more than one factor at 0.40 or greater were assigned to the factor with the highest loading, and ten items that were not related to any factor were excluded from the next steps of the analysis. In the result, a total of seven factors were extracted from the remaining 53 traits. The adequacy of this seven-component solution was determined by using the following criteria: all seven factors had eigenvalues larger than 1; the seven-factor solution explained a high level of variance (56 percent); a significant dip in the Scree plot followed by the 
seventh factor; the factor loading score for each factor $(>0.4)$; and the meaningfulness of each dimension (Aaker, 1997; Kim et al., 2010). The seven factors accounted for approximately 56 percent of the total variance and met all the criteria we used. They are listed as follows:

1. (1) Competence.

2. (2) Attractiveness.

3. (3) Sincerity.

4. (4) Innovation.

5. (5) Activity.

6. (6) Excitement.

7. (7) Ruggedness.

Determination of the factor labels followed a comparison of existing brand personality dimensions, which were identified in previous studies that use a similar methodology (Aaker, 1997; Aaker et al., 2001; Hosany et al., 2006). Newly emerging factors, which were not present in the literature, were named after the representative attributes within the factor. Table I shows all seven factors extracted in this study, their respective eigenvalues, the variance explained by each, and the traits with the highest item-to-total correlation (see Table I). 


\begin{tabular}{|c|c|c|c|c|c|c|c|}
\hline Traits & Competence & ttractiveness & Sincerity & Innovation & Activity 1 & Excitement & Ruggednes \\
\hline Competitive & 0.72 & 0.23 & 0.00 & 0.14 & 0.09 & 0.09 & 0.04 \\
\hline Confident & 0.72 & 0.28 & 0.12 & 0.17 & 0.07 & 0.12 & 0.08 \\
\hline Determined & 0.69 & 0.13 & 0.15 & 0.11 & 0.26 & 0.18 & 0.12 \\
\hline Hard working & 0.66 & 0.02 & 0.25 & 0.22 & 0.19 & 0.24 & 0.15 \\
\hline Courageous & 0.64 & 0.12 & 0.23 & 0.25 & 0.08 & 0.14 & 0.09 \\
\hline Motivated & 0.63 & 0.20 & 0.19 & 0.13 & 0.11 & 0.14 & -0.03 \\
\hline Powerful & 0.61 & 0.22 & 0.16 & 0.09 & 0.19 & 0.10 & 0.16 \\
\hline Strong & 0.59 & 0.25 & 0.21 & 0.01 & 0.29 & 0.06 & 0.34 \\
\hline Successful & 0.56 & 0.49 & 0.14 & 0.10 & 0.14 & 0.02 & -0.09 \\
\hline Real & 0.54 & 0.17 & 0.25 & 0.24 & 0.16 & 0.03 & 0.14 \\
\hline Ambitious & 0.54 & 0.16 & 0.19 & 0.18 & 0.37 & 0.06 & -0.03 \\
\hline Supportive & 0.53 & 0.22 & 0.31 & 0.15 & 0.17 & 0.12 & 0.26 \\
\hline Energetic & 0.52 & 0.29 & 0.18 & 0.07 & 0.13 & 0.38 & 0,09 \\
\hline Reliable & 0.48 & 0.10 & 0.14 & 0.32 & 0.12 & 0.01 & 0.15 \\
\hline Team-oriented & 0.46 & 0.43 & 0.24 & 0.07 & 0.08 & 0.09 & 0.03 \\
\hline Intense & 0.45 & 0.22 & 0.24 & 0.14 & 0.25 & 0.04 & 0.24 \\
\hline Outgoing & 0.40 & 0.14 & 0.18 & 0.22 & 0.18 & 0.24 & 0.11 \\
\hline Spirited & 0.40 & 0.12 & 0.36 & 0.24 & 0.12 & 0.34 & 0.07 \\
\hline Up-to-date & 0.35 & 0.69 & 0.04 & 0.28 & 0.13 & 0.13 & 0.07 \\
\hline Popular & 0.33 & 0.69 & 0.22 & 0.00 & 0.10 & -0.09 & -0.09 \\
\hline Trendy & 0.17 & 0.67 & 0.06 & 0.17 & 0.10 & 0.17 & 0.12 \\
\hline Young & 0.14 & 0.59 & 0.12 & 0.13 & 0.10 & 0.07 & 0.07 \\
\hline Attractive & 0.33 & 0.53 & 0.35 & 0.19 & 0.05 & 0.36 & -0.03 \\
\hline Cool & 0.30 & 0.49 & 0.05 & 0.30 & 0.21 & 0.16 & -0.07 \\
\hline Relaxed & 0.08 & 0.24 & 0.70 & 0.01 & 0.09 & 0.14 & 0.15 \\
\hline Respectful & 0.26 & 0.17 & 0.67 & 0.26 & 0.13 & 0.02 & -0.03 \\
\hline Honest & 0.28 & -0.02 & 0.61 & 0.40 & 0.08 & 0.17 & 0.14 \\
\hline Friendly & 0.29 & 0.11 & 0.58 & 0.23 & -0.06 & 0.40 & 0.04 \\
\hline Down-to-earth & 0.15 & -0.06 & 0.55 & 0.25 & -0.10 & 0.11 & 0.17 \\
\hline Solid & 0.36 & 0.13 & 0.54 & 0.14 & 0.28 & 0.10 & 0.13 \\
\hline Practical & 0.06 & 0.34 & 0.52 & 0.04 & 0.30 & -0.16 & 0.08 \\
\hline Flexible & 0.28 & 0.33 & 0.43 & 0.11 & 0.07 & 0.29 & 0.21 \\
\hline Unique & 0.13 & 0.15 & 0.22 & 0.76 & 0.04 & 0.20 & 0.10 \\
\hline Original & 0.23 & 0.27 & 0.23 & 0.62 & -0.02 & -0.08 & 0.16 \\
\hline Intelligent & 0.29 & 0.11 & 0.32 & 0.57 & 0.40 & 0.12 & 0.02 \\
\hline Independent & 0.35 & -0.01 & 0.27 & 0.55 & 0.34 & 0.07 & -0.06 \\
\hline Open to change & 0.14 & 0.29 & 0.16 & 0.55 & 0.04 & 0.23 & 0.22 \\
\hline Modern & 0.10 & 0.45 & -0.07 & 0.54 & 0.14 & 0.20 & 0.14 \\
\hline Innovative & 0.30 & 0.20 & 0.37 & 0.44 & 0.13 & 0.30 & 0.25 \\
\hline Healthy & 0.32 & 0.13 & 0.19 & 0.09 & 0.63 & 0.12 & 0.12 \\
\hline Fast & 0.35 & 0.28 & 0.00 & 0.05 & 0.61 & 0.12 & 0.16 \\
\hline Disciplined & 0.30 & -0.14 & 0.03 & 0.25 & 0.46 & 0.02 & 0.00 \\
\hline Active & 0.42 & 0.35 & -0.04 & 0.07 & 0.43 & 0.03 & -0.14 \\
\hline Athletic & 0.42 & 0.44 & -0.09 & -0.09 & 0.42 & 0.05 & -0.04 \\
\hline Organized & 0.30 & 0.07 & 0.35 & 0.32 & 0.40 & 0.07 & -0.03 \\
\hline Enthusiastic & 0.32 & 0.07 & 0.10 & 0.19 & 0,21 & 0.64 & 0.09 \\
\hline Fun & 0.21 & 0.40 & 0.19 & 0.22 & 0.33 & 0.50 & 0.08 \\
\hline Cheerful & 0.12 & 0.16 & 0.35 & 0.22 & 0.11 & 0.50 & -0.05 \\
\hline Exciting & 0.41 & 0.34 & 0.36 & 0.20 & 0.10 & 0.42 & 0.00 \\
\hline Rugged & 0.06 & -0.06 & 0.04 & 0.14 & -0.05 & 0.00 & 0.77 \\
\hline Tough & 0.39 & 0.17 & 0.16 & 0.10 & 0.31 & -0.02 & 0.60 \\
\hline Technical & 0.16 & 0.01 & 0.25 & 0.23 & 0.15 & 0.22 & 0.50 \\
\hline Sophisticated & 0.20 & 0.07 & 0.31 & 0.18 & 0.08 & 0.32 & 0.40 \\
\hline Eigenvalues & 22.68 & 3.30 & 2.63 & 1.84 & 1.74 & 1.60 & 1.45 \\
\hline$\%$ of variance & 36.00 & 5.24 & 4.17 & 2.93 & 2.77 & 2.54 & 2.30 \\
\hline Cumulative \% & 36.00 & 41.24 & 45.41 & 48.34 & 51.11 & 53.65 & 55.95 \\
\hline
\end{tabular}

Notes: An estimation sample is derived from a random half of the pooled data $(n=210,420 / 2)$. Factor $\quad$ Sportswear brand loadings that are 0.4 or larger are set in italic 
To represent each brand personality dimension accurately, the analysis also included a facet identification step. Adopting the process used by Costa and McCrae (1992), Aaker (1997) found a distinct set of facets that provided a structure to justify which attributes to select to represent each dimension as well as texture to understand the dimensions in greater detail. For example, the American Sincerity dimension consists of four facets: down-to-earth, honesty, wholesomeness, and cheerfulness (Aaker et al., 2001). Using the same process, identification of facets within the seven factors was carried out by means of principal components analyses with varimax rotation, performed separately for each dimension (Aaker, 1997; Aaker et al., 2001). The analysis revealed that the Competence factor has three facets (determined, successful, and reliable); Sincerity (honest and flexible) and Activity (athletic and disciplined) have two each; while the factors Attractiveness, Innovation, Excitement, and Ruggedness showed a one-dimension structure. Figure 1 depicts selected brand personality traits and their corresponding facets and dimensions.

\section{Confirmatory factor analysis (CFA)}

EFA is useful for data reduction purposes, but it does not provide evidence of the dimensionality of measures essential in scale development (Gerbing and Anderson, 1988). In this study, CFA was used to test the validity of the items.

Cronbach's a coefficients were used to examine the internal consistency of the items before conducting a CFA. Cronbach's a coefficients calculated for each of the seven dimensions indicated high levels of internal reliability: Competence 1/4 0.94, Attractiveness 1/4 0.86, Sincerity 1/4 0.88, Innovation 1/4 0.87, Activity 1/4 0.79, Excitement 1/4 0.80, and Ruggedness $1 / 40.69$. We performed CFA using Amos 19 (the structural equation modeling package). This analysis used the remaining random half of the pooled data (n 1/4 210, 420/2) as the secondary holdout sample to be used for validation and predication. Model fit criteria suggested by $\mathrm{Hu}$ and Bentler (1999) were used for the measurement model: w2/df, goodness of fit (GFI), adjusted goodness of fit (AGFI), comparative fit index (CFI), root mean square residual (RMR), and root mean square error of approximation (RMSEA). Acceptable models should have w2/dfp3, AGFIX0.80, RMRp0.1, RMSEAp0.1, and GFI and CFI 40.90. Fit indices of the measurement model were satisfactory overall: w2/df 1/4 2.00, GFI 1/4 0.88, AGFI 1/4 0.83, CFI 1/4 0.90, RMR 1/4 0.05, and RMSEA 1/4 0.05, suggesting that the seven-component model is stable within the holdout data.

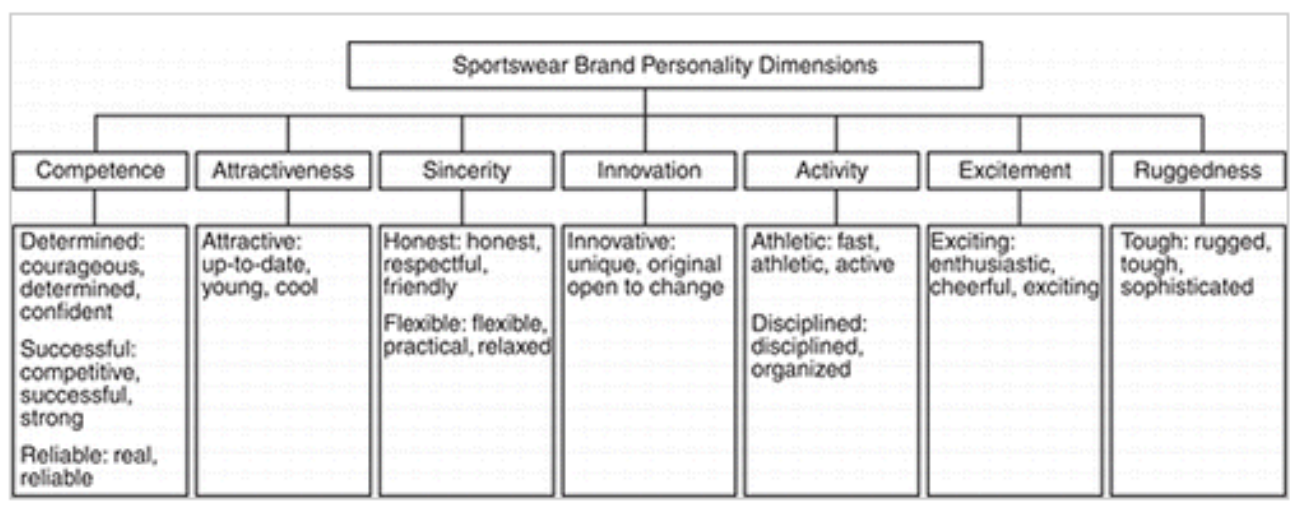

Figure 1. Seven sportswear brand personality dimensions and their facets

All factor loadings were significant and varied from 0.60 to 0.78 , satisfying the convergent validity criteria. Unidimensionality and convergent validity of the constructs were assessed by 
the composite reliability measure and the average variance extracted (AVE), respectively. The composite reliability varied from 0.60 to 0.72 , satisfying the criteria of 0.6. AVE varied from 0.58 to 0.74 , thus satisfying the criteria of 0.50 (Fornell and Larcker, 1981). In addition, discriminant validity was evaluated by comparing the AVE estimates for each construct with the square of the parameter estimates between the two constructs. According to Fornell and Larcker (1981), discriminant validity is achieved if the AVE of each construct exceeds the square of the standardized correlations between pairs of constructs. All AVE estimates were greater than the squared correlations between all constructs in this study. Thus, both convergent validity and discriminant validity were considered to have been established.

\section{The effect of demographic factors on respondents' brand personality perception}

In order to investigate the effect of demographic variables (gender, age, and race) on respondents' brand personality evaluations, one-way analysis of variance (ANOVA) was used to determine whether there was a significant mean difference in the respondent's perceptions of the seven dimensions of brand personality identified for sportswear brands. The results of ANOVA tests showed that there were no significant differences in mean scores across gender and age groups at the 0.05 level of significance. Asian respondents indicated a lower perception toward the dimension of Activeness than did both Caucasian and African-American respondents. However, we found no statistical difference between racial groups in their perceptions of other six dimensions of brand personality for sportswear brands.

\section{Discussion and implications}

This research aims to explore and identify the personalities associated with sportswear brands. To this purpose, a study focussing on sportswear brands that follows the existing framework was conducted. To identify the brand personality dimensions for sportswear brands, a total of 420 subjects rated the top ten sportswear brands on 63 personality traits. The results of an exploratory principal components factor analysis suggested that consumers perceive that sportswear brands have seven distinct personality dimensions and 53 personality traits (ten items were deleted during the EFA): Competence, Attractiveness, Sincerity, Innovation, Activity, Excitement, and Ruggedness. The results of a CFA provided additional support for the stability of the seven dimensions. In summary, personality of sportswear brands can be measured with a sevendimensional, 53-item scale.

Since sportswear is uniquely positioned between the fashion and sports industry, our results show that the personality of sportswear brands is a good combination of the Aaker (1997) brand personality dimensions (Competence, Attractiveness, Sincerity, Excitement, and Ruggedness), characteristics associated with athletes (Competence, Attractiveness, Sincerity, Activity, and Ruggedness), and characteristics associated with fashion (Attractiveness, Innovation, and Excitement), which reflects consumers' increasing demand for stylish, functional, and versatile sports clothing and footwear products.

Five of these seven dimensions - Competence, Attractiveness (sophistication), Sincerity, Excitement, and Ruggedness - are congruent with the five dimensions of brand personality developed by (Aaker, 1997). The strong convergence between the findings from this study and 
Aaker's scale is not a surprising result. Aaker's 42-trait framework was designed and proven to be widely applicable across brands and product categories. In addition, 22 out of Aaker's original 42 traits remained in the final set of personality traits identified for sportswear brands in this study. The findings also support a recent study by Arora and Stoner (2009), which identifies Sincerity, Excitement, Competence, and Ruggedness as the personality dimensions for two athletic brands (Adidas and Nike) included in their study.

Remarkably, two new dimensions, namely Innovation and Activity, appeared in this study as dimensions of brand personality specifically for sportswear brands. They differed from the Big Five in human personality (Briggs, 1992) and the Big Five in brand personality (Aaker, 1997). This is not surprising, because these traits are some of the common themes that sportswear marketers use to characterize sportswear brands in the media. Innovation in this study depicts being unique, modern, and innovative. The emergence of the innovation dimension in this study may also be explained by the fact that consumers portray sportswear brands as innovative and modern. Nowadays, sportswear has become a common and popular category of clothing, as it gives young people a more relaxed lifestyle and greater versatility and comfort (Lau et al., 2006). Today's consumers look for sportswear products that not only address utilitarian needs but offer a hedonic value and provide a sense of uniqueness as well (Kaplan, 2009). They want sportswear to help them stay comfortable and, at the same time, make them look smart and fashionable when they exercise. Therefore, casual design and athletic design are converging in the sportswear industry (Lau et al., 2006). Sportswear companies are trying to push athletic innovation to its extreme to meet consumers' expectations and demand through modern product design, up-to-date technologies, and innovative marketing activities.

Another major finding of the study is the Activity dimension, which refers to characteristics such as fast, active, disciplined, and organized. This dimension is the reflection of characteristics defining athletes based on sportswear brands' personality. According to Williams and Krane (2001), not only are athletes physically fit, but they also have the ability to set a competitive routine or plan and stick to it. Celebrity endorsements (including celebrity-athlete endorsements) are widely used to generate attention for brands and connect brands with celebrities' personality traits (Bush et al., 2004; Keller, 2008). For decades, sportswear companies such as Adidas and Nike have prospered by linking their brands with athletes and sports stars such as Michael Jordan and David Beckham. Our results imply that marketing efforts of sportswear brands have done a great job in leveraging unique and positive brand associations of athletes and sports stars in order to transfer the positive associations to the brands and create strong brand images.

However, this study also suggests that consumers may seek more than innovation and athletic spirit when they select sportswear. The personality dimension of Competence consists of traits such as determined, confident, successful, and reliable. The brand personality described by this category clearly fits the top sportswear brands' (e.g. Nike, Adidas, and Reebok) leading position and good reputation in the sportswear market. This dimension may also be associated with personality traits of athletes to some extent, such as confident, hardworking, and team-oriented. The Attractiveness dimension, including up-to-date, popular, young and cool, seems to reflect the stylistic and attractive aspect of sportswear products and celebrity-athletes who represent well-known sportswear brands. The Sincerity dimension encompasses traits like honest, friendly, practical, and flexible, which appear to reflect consumers' perceptions of high quality, high 
performance, and the family oriented image of the major sportswear brands (Maehle et al., 2011). The personality dimension of Excitement consists of traits such as enthusiastic, fun, and cheerful, which implies that sportswear brands are considered to be fun and are thus highly capable of generating interest. Consumers wear sportswear mainly for fun and exciting leisure and sports activities, which may explain why consumers attach a sense of excitement to sportswear brands. The Ruggedness dimension, including tough, technical, and sophisticated, suggests that sportswear brands are seen as outdoorsy and tough. This result comes as no surprise, because sportswear products powered by cutting-edge technology and performance can protect people during their outdoor sports and activities.

This research has both theoretical and practical implications. Theoretically, it makes three contributions. First, it developed a valid and reliable scale that measures personality for sportswear products and can be extended to other closely related industries, such as sporting goods and fashion accessories. Second, the findings confirm that consumers do associate particular brand personality dimensions with specific brand categories (such as sportswear). Third, the findings also show that the existing brand personality scales are applicable to sportswear brands. Practical applications of this research also exist. According to Aaker (1997), the measurement of brand personality can be managerially interesting, because it allows description of brands' personalities, and it also allows contrasting personalities of competing brands. In the sportswear industry, there is evidence that the top brands compete fiercely against each other for market share and customer loyalty. In such an environment, successful positioning and differentiation of the brand becomes crucial. Development of a strong brand personality clearly fosters the success of branding activities. Thus, the scale and the distinctive brand personality dimensions identified by this study can be used as a practical marketing tool for brand managers in the sportswear market. Specifically, we believe that our findings would help managers better understand the image of their brand in the minds of consumers, better distinguish their brand from competing brands, and further identify the target market that is sensitive to the personality traits attached to their brand.

\section{Limitations and future research}

Since this study was deliberately performed for a specific category (sportswear), our findings only reflect American young consumers' brand personality perception of sportswear brands. For this reason, the scale ought to be reassessed with other product categories and with consumers from different cultural backgrounds and in different age groups (Aaker et al., 2001). In addition, from both an academic and practical standpoint, it would also be interesting to examine the antecedents and consequences of brand personality in the sportswear industry. Therefore, future studies could examine how to create brand personality through a variety of marketing variables (such as advertising and sponsorship) and what the impact of brand personality is on other variables such as consumer loyalty and purchase intention toward sportswear brands.

\section{References}

Aaker, J.L. (1997), "Dimensions of brand personality", Journal of Marketing Research, Vol. 34 No. 3, pp. 347-356. 
Aaker, J.L. (1999), "The malleable self: the role of self-expression in persuasion", Journal of Marketing Research, Vol. 36 No. 1, pp. 45-57.

Aaker, J.L., Benet-Martı'nez, V. and Garolera, J. (2001), "Consumption symbols as carriers of culture: a study of Japanese and Spanish brand personality constructs", Journal of Personality and Social Psychology, Vol. 81 No. 3, pp. 492-508.

Aggarwal, P. and McGill, A.L. (2007), "Is that car smiling at me? Schema congruity as a basis for evaluating anthropomorphized products", Journal of Consumer Research, Vol. 34 No. 4, pp. 468-479.

Ambroise, L., Ben Sliman, S., Bourgeat, P., De Barnier, V., Ferrandi, J.-M., Merunka, D., Roehrich, G. and Valette- Florence, P. (2005), "The impact of brand personality on attitude and commitment towards the brand", CD-ROM, Proceedings of the 32nd International Research Seminar in Marketing, Marketing Communications and Consumer Behavior, La Londe les Maures, June 7-10.

Ang, S.H. and Lim, E.A.C. (2006), "The influence of metaphors and product type on brand personality perceptions and attitudes", Journal of Advertising, Vol. 35 No. 2, pp. 39-53.

Arora, R. and Stoner, C. (2009), "A mixed method approach to understanding brand personality”, Journal of Product \& Brand Management, Vol. 18 No. 4, pp. 272-283.

Austin, J.R., Siguaw, J.A. and Mattila, A.S. (2003), “A re-examination of the generalizability of the Aaker brand personality measurement framework", Journal of Strategic Marketing, Vol. 11 No. 2, pp. 77-92.

Avis, M. (2012), "Brand personality factor based models: a critical review", Australasian Marketing Journal, Vol. 20 No. 1, pp. 89-96.

Azoulay, A. and Kapferer, J.-N. (2003), "Do brand personality scales really measure brand personality?", Journal of Brand Management, Vol. 11 No. 2, pp. 143-155.

Belk, R.W. (1988), “Possessions and the extended self”, Journal of Consumer Research, Vol. 15 No. 2, pp. 139-168.

Biel, A.L. (1993), "Converting image into equity", in Aaker, D.A. and Biel, A.L. (Eds), Brand Equity and Advertising, Lawrence Erlbaum Associates, Hillsdale, NJ, pp. 67-82.

Bosnjak, M., Bochmann, V. and Hufschmidt, T. (2007), "Dimensions of brand personality attributions: a person-centric approach in the German cultural context", Social Behavior and Personality: An International Journal, Vol. 35 No. 3, pp. 303-316.

Brakus, J.J., Schmitt, B.H. and Zarantonello, L. (2009), "Brand experience: what is it? How is it measured? Does it affect loyalty?”, Journal of Marketing, Vol. 73 No. 3, pp. 52-68. 
Briggs, S.R. (1992), “Assessing the five-factor model of personality description”, Journal of Personality and Social Psychology, Vol. 60 No. 2, pp. 253-293.

Bush, A.J., Martin, C.A. and Bush, V.D. (2004), "Sports celebrity influence on the behavioral intentions of Generation Y”, Journal of Advertising Research, Vol. 44 No. 1, pp. 108119.

Caprara, G.V., Barbaranelli, C. and Guido, G. (2001), "Brand personality: how to make the metaphor fit?”, Journal of Economic Psychology, Vol. 22 No. 3, pp. 377-395.

Chen, Q. and Rodgers, S. (2006), "Development of an instrument to measure web site personality", Journal of Interactive Advertising, Vol. 7 No. 1, pp. 33-46.

Commerzbank (2008), “"Adidas', equity research”, available at: www.wikinvest.com/ (accessed August 8, 2012).

Costa, P.T. and McCrae, R.R. (1992), Revised NEO Personality Inventory and NEO Five Factor Inventory Professional Manual, Psychological Assessment Resources, Odessa, FL.

Cui, A.P., Albanese, P.J., Jewell, R.D. and Hu, M.Y. (2008), "Profiling the brand personality of specific brands", Advances in Consumer Research, Vol. 35, pp. 534-541.

Deng, T. (2009), “'Just done it' - Nikes new advertising plan facing global economic crisis”, International Journal of Business and Management, Vol. 4 No. 3, pp. 102-105.

Ekinci, Y. and Hosany, S. (2006), "Destination personality: an application of brand personality to tourism destinations", Journal of Travel Research, Vol. 45 No. 2, pp. 127-139.

Escalas, J.E. and Bettman, J.R. (2005), "Self-construal, reference groups, and brand meaning”, Journal of Consumer Research, Vol. 32 No. 3, pp. 378-389.

Fornell, C. and Larcker, D.F. (1981), "Evaluating structural equation models with unobservable variables and measurement error", Journal of Marketing Research, Vol. 18 No. 1, pp. 3950 .

Fournier, S. (1998), "Consumers and their brands: developing relationship theory in consumer research", Journal of Consumer Research, Vol. 24 No. 4, pp. 343-373.

Freling, T.H. and Forbes, L.P. (2005), "An empirical analysis of the brand personality effect", Journal of Product \& Brand Management, Vol. 14 No. 7, pp. 404-413.

Gerbing, D.W. and Anderson, J.C. (1988), “An updated paradigm for scale development incorporating unidimensionality and its assessment", Journal of Marketing Research, Vol. 25 No. 2, pp. 186-192. 
Geuens, M., Weijters, B. and De Wulf, K. (2009), “A new measure of brand personality”, International Journal of Research in Marketing, Vol. 26 No. 2, pp. 97-107.

Hosany, S., Ekinci, Y. and Uysal, M. (2006), "Destination image and destination personality: an application of branding theories to tourism places", Journal of Business Research, Vol. 59 No. 5, pp. 638-642.

Hu, L. and Bentler, P.M. (1999), "Cutoff criteria for fit indexes in covariance structure analysis: conventional criteria versus new alternatives", Structural Equation Modeling, Vol. 6 No. 1 , pp. 1-55.

just-style.com (2009), "Sportswear market to sprint past recession", available at: www.juststyle.com/analysis/sportswear-market-to-sprint-past-recession_id104903.aspx (accessed August 6, 2012).

Kaplan, M.D. (2009), "The relationship between perceived innovativeness and emotional product responses: a brand oriented approach", Innovative Marketing, Vol. 5 No. 1, pp. $39-47$.

Kaplan, M.D., Yurt, O., Guneri, B. and Kurtulus, K. (2010), "Branding places: applying brand personality concept to cities", European Journal of Marketing, Vol. 44 Nos 9/10, pp. 1286-1304.

Keller, K.L. (2008), Strategic Brand Management: Building, Measuring, and Managing Brand Equity, 3rd ed., Prentice Hall, Upper Saddle River, NJ.

Kim, J., Baek, T.H. and Martin, H.J. (2010), "Dimensions of news media brand personality", Journalism \& Mass Communication Quarterly, Vol. 87 No. 1, pp. 117-134.

Kumar, R. (1999), Research Methodology: A Step-by-Step Guide for Beginners, Sage Publications, Thousand Oaks, CA.

Lau, M.-M., Chang, M.-T., Moon, K.-L. and Liu, W.-S. (2006), “The brand loyalty of sportswear in Hong Kong”, Journal of Textile and Apparel, Technology and Management, Vol. 5 No. 1, pp. 1-13.

Maehle, N., Otnes, C. and Supphellen, M. (2011), "Consumers' perceptions of the dimensions of brand personality”, Journal of Consumer Behaviour, Vol. 10 No. 5, pp. 290-303.

Milas, G. and Mlačić, B. (2007), "Brand personality and human personality: findings from ratings of familiar Croatian brands", Journal of Business Research, Vol. 60 No. 6, pp. $620-626$.

Newbery, M. (2009), Global Market Review of Active Sportswear and Athletic Footwear Forecasts to 2016, Aroq Limited, Worcestershire. 
Phau, I. and Lau, K.C. (2001), "Brand personality and consumer self-expression: single or dual carriageway?", The Journal of Brand Management, Vol. 8 No. 6, pp. 428-444.

Plummer, J.T. (1985), "How personality makes a difference", Journal of Advertising Research, Vol. 24 No. 6, pp. 27-31.

Plummer, J.T. (2000), "How personality makes a difference", Journal of Advertising Research, Vol. 40 No. 6, pp. 79-84.

Sirgy, M.J. (1982), "Self-concept in consumer behavior: a critical review", Journal of Consumer Research, Vol. 9 No. 3, pp. 287-300.

Sung, Y. (2011), “The effect of usage situation on Korean consumers' brand evaluation: the moderating role of self-monitoring", Journal of Consumer Behaviour, Vol. 10 No. 1, pp. 31-40.

Sung, Y. and Kim, J. (2010), "Effects of brand personality on brand trust and brand affect", Psychology and Marketing, Vol. 27 No. 7, pp. 639-661.

Sung, Y. and Tinkham, S.F. (2005), "Brand personality structures in the United States and Korea: common and culture-specific factors", Journal of Consumer Psychology, Vol. 15 No. 4, pp. 334-350.

Tong, X. and Hawley, J.M. (2009), "Measuring customer-based brand equity: empirical evidence from the sportswear market in China", Journal of Product \& Brand Management, Vol. 18 No. 4, pp. 262-271.

Venable, B.T., Rose, G.M., Bush, V.D. and Gilbert, F.W. (2005), "The role of brand personality in charitable giving: an assessment and validation", Journal of the Academy of Marketing Science, Vol. 33 No. 3, pp. 295-312.

Williams, J.M. and Krane, V. (2001), "Psychological characteristics of peak performance", in Williams, J.M. (Ed.), Applied Sport Psychology: Personal Growth to Peak Performance, 4th ed., Mayfield, Mountain View, CA, pp. 137-147.

Yin, R.K. (1989), Case Study Research, Design and Methods, Sage, Newbury Park, CA. 